Meorosconomlo Adjustment and Gromth

Country Economics Department

The World Bank

January 1991

WPS 574

\title{
Public Policies and Saving in Developing Countries
}

\author{
Vittorio Corbo \\ and \\ Klaus Schmidt-Hebbel
}

Developing countries can increase their national saving rate best by increasing govermment saving. The most effective way to increase national saving is through a permanent tax hike, a cut in current public spending, and a macroeconomic framework in which inflation is low and incentives are predictable. 


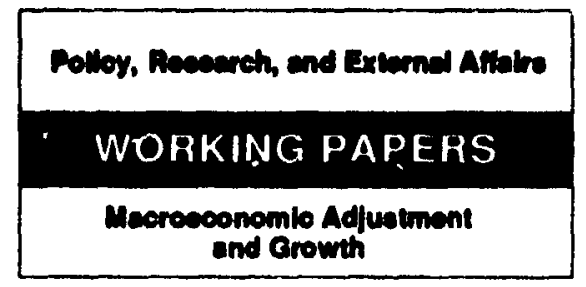

WPS 574

This paper - a product of the Macroeconomic Adjustment and Growth Division, Country Economics Department - is part of a larger effort in PRE to improve the understanding of the transition from adjustment to growth. Copies are available free from the World Bank, $1818 \mathrm{H}$ Street NW, Washington DC 20433. Please contact Susheela Jonnakuty, room N11-039, extension 39074 (29 pages).

Corbo and Schmidt-Hebbel analyze the effectiveness of public policy in raising saving in developing countries, drawing on estimates of consumption functions for 13 developing countries. First, they provide evidence from timeseries and panel data on how liquidity constraints affect consumption functions. This suggests that a rise in public saving does not produce an equal reduction in private saving.

Second, they present direct evidence of the link between private consumption and govemment saving - based on a more general consumption specification implemented for $1980-87$ country panel data. These show that indirect effects of public policies on private saving through changes in domestic inflation and real interest rates - are negligible. But cuts in current public spending and current tax hikes significantly affect private savings.

Increasing public saving by cutting currentperiod public expenditures by $\$ 1$ reduces private saving by only 16 to 50 cents. Permanent cuts in public spending reduce private saving by 47 to 50 cents.

Not surprisingly, a higher permanent tax hike has less of an effect on private saving than a transitory tax hike. For each $\$ 1$ increase in permanent taxes, private saving declines only 23 to 26 cents. Increasing only current-period taxes reduces private saving between 48 and 65 cents.

Increasing taxes and improving tax compliance are the most efficient ways to reduce public deficits when traditional tax revenue is low and inefficient tax levies (such as the inflation tax) are high and widespread. Finally, public policy can help raise private savings and make their use more efficient by providing a macroeconomic framework in which inflation is low and incentives are predictable.

The PRE Working Paper Series disseminates the findings of work under way in the Bank's Policy, Research, and External Affairs Complex. An objective of the series is to get these findings out quickly, even if presentations are less than fully polished. The findings, interpretations, and conclusions in these papers do not necessarily represent official Bank policy. 
Public Policies and Saving in Developing Countries

\author{
by \\ Vittorio Corbe \\ and \\ Klaus Schmidt-Hebbel*
}

Table of Contents

2. Saving and Investment Rates: A First Look 3

3. Is There Evidence of Liquidity Constraints? 3

4. Private Consumption and Public Policies 10

5. Estimeting t.le Effects of Public Sector Saving on 18 Private Saving

6. Conclusions 21

$\begin{array}{ll}\text { References } & 23\end{array}$

$\begin{array}{ll}\text { Appendices } & 25\end{array}$

* The authors thank Juan Carlos Lerda and Jorge Marshall (ECLAC, Santiago, Chile) for generous data provision. We benefited greatly from useful discussions with and comments by M. Blejer, R. Caballero, R. Dornbusch, W. Easterly, S. Edwards, P. Honohan, P. Krugman, and P. Mujica. An earlier version of this paper also benefited from the comments by participants at the NBER-PUC conference in Mangaratiba, Brazil (March 1990), two world Bank conferences, and the second Regional Meeting of the ECLAC Project on Fiscal Policies in Santiag,, Chile (August 1990). We are grateful to José Miguel Cruz for his efficient research assistance. 


\section{Introduct1on}

"The most direct tool at the government's disposal for altering the national saving rate is changes in the level of public saving or dissaving ... The potentially direct Iinkages between the race of public saving and the level of national saving suggest that if altering the rate of nations oaving is policy goal, this goal should be asolgned to deficit policy" (L. Summers (1985), PP. 8-9).

In the late 1970 s and early 1980 s lnw international real interest rates and easy access to private capital markets facilitated a large expansion in developing country comestic expenditures that resulted in persistent current account deficits and accumulation of large external debts. Public external debt accumulation in many cases was much above what can be accounted for by current account deficits, as public sector borrowing also financed capital flights. When voluntary commercial lending was severely curtalled -- following Mextco's difficulties in serving its debt -- the boom transformed into a major crisis in many countrles. When after 1982 forelgn borrowing was not more avallable, the private and public sector deficits (Investments minus savings) had to be cut accordingly.

The reduction in foreign saving was associated in many cases with a recession and a decline in national saving. The public saving to GDP ratio dropped as the public sector had to cope with higher forelgn interest payments resulting from increased debt stocks, higher interest rates, and real devaluations. At the same time revenues fell together with income. The decline In the private saving to GDP ratio followed from partial consumption omoothing during the cyclical downturn. The final result was lower saving, a recession, higher real interest rates and a collapse in investment.

Investment rates declined for several reasons. Pubilc investment contracted because of the deterioration in fiscal conditions and the Incapacity or unwillingness of governments to reduce current expenditures. Private Investment declined because of lower or negative growth, higher real interest rates and an increase in uncertainty associated to the macroeconomic crisis and Initial doubts about the oustainibility of the change in relative prices and 
incentives.

For countries tc resume sustainable growth, major distortions have to be reduced and Investment rates will need to increase from the depressed 1983-85 levels. Recovery of investment requires a predictable macroeconomic environment, stable incentives and higher saving rates at a given real interest rate. As it 18 most likel: that foreign saving will remain low in the foreseesble future, a major effort to increase national saving will be needed.

Emplrical evidence shows that private saving rates are usually not very sensitive to changes in macroeconomic and financlal policles. Ralsing real. interest rates often induces shifts in portfollo compositior but has ambiguous or minor effects on saving. However, private saving rates are very sensitive to the economic cycle as a result of consumption smoothing.

Public sector saving rates can be increased more directly through reforms of public enterprises. local government finances and the central government budget. However, if private saving rates are negatively affected by an increase In public saving rates, then the prospects for an Increase in national saving rates w111 be much reduced. The effect of public saving on national saving is an empirical question which is the main focus of this paper.

The rest of the paper is divided into 5 sections. Section 2 reviews the evidence on saving and investment rates in a group of 13 developing countries. Next a two-step approach is followed to analyze the impact of public policies, and particularly of public saving, on private saving. First, section 3 provides evidence on the importance of liquidity constraints affecting consumption levels in developing countries and thus gives indirect support to the notion that an increase in public saving does not result in an equal reduction in private saving. The second step, in section 4, provides direct evidence on the link between private consumption and government saving using a more general consumption specification. Section 5 analyzes the implications of our findings for the design of pollcies to promote an increase of national saving. Section 6 presents the main conclusions. 


\section{Saving and Investment Rates: A First Lock}

Table 1 presente data on average saving and investment rates in a group of 1' countries, 8 of them in Latin America. The average national oaving rate in this sample of developing countries dropped substantially up to 1982-83 and -tarted alow and partial recovery thereafter. The average forelgn saving rate reached its peak in 198 ! and then decreased substantially reaching its lowest value in 1986. Gross domest1c investment also reached 1ts peak in 1981 and then decreased continuously thereafter reaching its lowest value in 1984. Frcm 1984 to 1987 the average gross domest1c investment rate of these countries increased almost 2 percentage points of GDP. The recovery of national saving, starting in 1984, 1s caused by some increase in public saving and a strong recovery of private saving rates, which have risen by more than 3 percentage points of GDP since 1983 .

We conclude from this preliminary evidence that for developing countries, In the short run, the evolution of the national saving rate is mostly accounted by movements in the private saving rate and to a lesser extent by changes in public saving. To different degrees, both private and public saving rates appear to be procyclical. This suggests that varlations in public saving are not (entirely) offset by private saving changes.

In the following two sections we examine this evidence in a more systematic way using individual country data and controlling for other factors.

\section{Is there Evidence of Liquidity Constraints?}

In assessing the effect of public policies, and particularly public saving. on private saving, we follow a two-step approach. First, in this section we test the perwanent income hypothesis by comparing the sensitivity 
Table 1

SAVING AND INVES INENT RSTES IN 13 DEVELOPING COUNTRIES: $1980-87$

(7 of GDP)

\begin{tabular}{llllll}
\hline & $\begin{array}{l}\text { Private } \\
\text { Saving }\end{array}$ & $\begin{array}{l}\text { Public } \\
\text { Saving }\end{array}$ & $\begin{array}{l}\text { National } \\
\text { Saving }\end{array}$ & $\begin{array}{l}\text { Foreign } \\
\text { Saving }\end{array}$ & $\begin{array}{c}\text { Gross Dotsestic } \\
\text { Inve s m n t }\end{array}$ \\
\hline & & & & & \\
1980 & 8.3 & 9.4 & 17.6 & 4.9 & 22.5 \\
1981 & 7.7 & 8.0 & 15.7 & 7.4 & 23.1 \\
1982 & 6.2 & 7.4 & 13.6 & 7.0 & 20.6 \\
1983 & 5.9 & 7.2 & 13.1 & 4.9 & 18.0 \\
1984 & 6.6 & 7.8 & 14.3 & 2.9 & 17.3 \\
1985 & 6.4 & 8.3 & 14.8 & 2.7 & 17.5 \\
1986 & 7.7 & 7.6 & 15.3 & 2.2 & 17.5 \\
1987 & 9.3 & 7.3 & 16.7 & 2.8 & 19.5 \\
& & & & & \\
\hline
\end{tabular}

Notes:

(1) The Latin American countries are: Argentina, Braz11, Chile, Colombia, Costa Rica, Mexico, Peru, Venezuela, and the non-Latin countries are Ghana, Pakistan, Philippines, Thailand and Zimbabwe.

(11) The rat1os are calculated as unwelghted sverages of country current price data.

(111) The sources for national saving, forelgn saving, gross domestic investment and GDP is the Andrex Data Base of the World Bank. See appendix 2 .

(1v) Public saving is computed as revenue minus expenditures -- excluding the inflation component of domestic debt -- of the consolidated non-financial public sector. 
of private consisofiton to permanert inr we with its dependence on current income and liquid wealth in developing countrles. If and by how much consumers react to current income and asset holdings sheds indirect light on the effectiveness of flacal policies an raising aggregate saving by increasing public saving. Section 4 pursues the second step, by analyzing the senoitivity of private conoumption to a broader set of income measures, public policies and relevant prices.

Following Hayash (1982) we assume the existence of two types of conoumere.' The first group is composed by rational intertemporal-optimizing Individuals whose stationary consumption levels follow Hall's (1978) random walk process consistent with the permansnt income hypothesis (PIH). The second group makes 1ts consumption decisions influenced by current income and liquid asset holdings, because it elther faces liquidity constraints or is uncertain abou: its permanent income levels. ${ }^{2}$

The following reduced-form equation reflects aggregate consimption behavior derived by adding the consumption processes for the two groups (Appendix 1 presents the derivation of the corresponding structural form):

$$
c_{t}=\theta_{0}+\theta_{1} c_{t-1}+\theta_{2} y_{t}-\theta_{3} y_{t-1}+\theta_{1} m_{t}-\theta_{3} u_{t-1}+v_{1 t}
$$

where $c$ is private consumption, $y$ is income, w 18 the sim of monet and quasimonetary asset holdings (broad money), $v_{1}$ is a stochastic error term, and $t$ is - tiroe Index. All variables are real, per capita values referred :0 the agregate economy.

'Montiel an 3 Haque (1987) and Corbo and de Melo (1989), among others, have used a similar assumption to test for the presence of liquidity constraints.

2 Uncertainty referred to permanent income or wealth levels due to the fact that income does not follow a stable time series process and hence future income levels are hard to predict leads to static or adaptive expectations of future variables even if consumers are rational forward-looking optimizers who oo not Eace Ilquidity constraints (see Schmidt-Hebbel, 1987). Th1s type of uncertainty seems to be a relevant characterization of income processes subject to disparate forelgn and domestic policy shocks, observed in many developing economies during the elghties. 
Under the permanent income hypothesis in ths simple, consumption randomwalk version, the coefficlent $\theta_{1}$ is $l$ and $a 11$ other coefficlel.cs are zero. The simple Reynesian theory and the uncertain permunent Income hypothesis postulate that $\theta_{0}$ and $\theta_{2}$ are positive while the remaining coefficients are zero. Cash-inadvance and other liquidity constraint hypotheses add money to current income as consumption determinants, Implying that $\theta_{1}$, is added to $\theta_{0}$ and $\theta_{2}$ as positive coefficiento under the null hypothesis.

However, mure than focusing on these extreme and partial hypotheses, our interest resides in deriving and comparing the coefficients - which a priori could all bo significantly different from zero - to shed 11ght on the relative role of permanent income, current income and monetary-financial assets in determining private consumption in developing countries.

Equation (1) was estimated for a sample of 13 developing countries which fointly represent 917 of the region's GNP in $1988 .^{3}$ Table 2.1 reports the country by country results for annual data covering the 1968-1988 sample perlod obtalned from two-stage least squares estimations." The results tend to confirm the foint existence of the two consumer groups as embodied in equation (1). Income and/or money are significant consumption determinants in all countries and lagged consumption is significant in 9 countries.

Country results differ widely from each other with respect to significancy levels and magnitudes of the 5 determinants; they are ali Individually significant in Chile and Colombia only. However, Hall's random walk hypothesis is widely rejected in 11 countrles, and marginally rejected in Argentina and Zimbabwe, as reflected by the $10 \mathrm{~g}-11$ kelihood ratio test statistics in the last column.

${ }^{3}$ The countries are Argentina, Braz11. Ch1le, Colombia, Costa Rica, Mexico, Peru, Veneziala, Ghana, Pakistan, Philippines, Thalland and Zimbabwe. For varlable definitions, data sources and transformations see appendix 2 .

"This instrumental variables method was applied because of potential biases due to the presence of the lagged dependent variable and current income in the right-hand side. See takle 2.1 for the instruments used here. 
Table 2.1

CONSIMYTION IN DEVELOPING COUNTRIES $(1968-1988)$

(country by country Isls et ination)

Dependent Variable: Per Capita Private Conoumption (c)

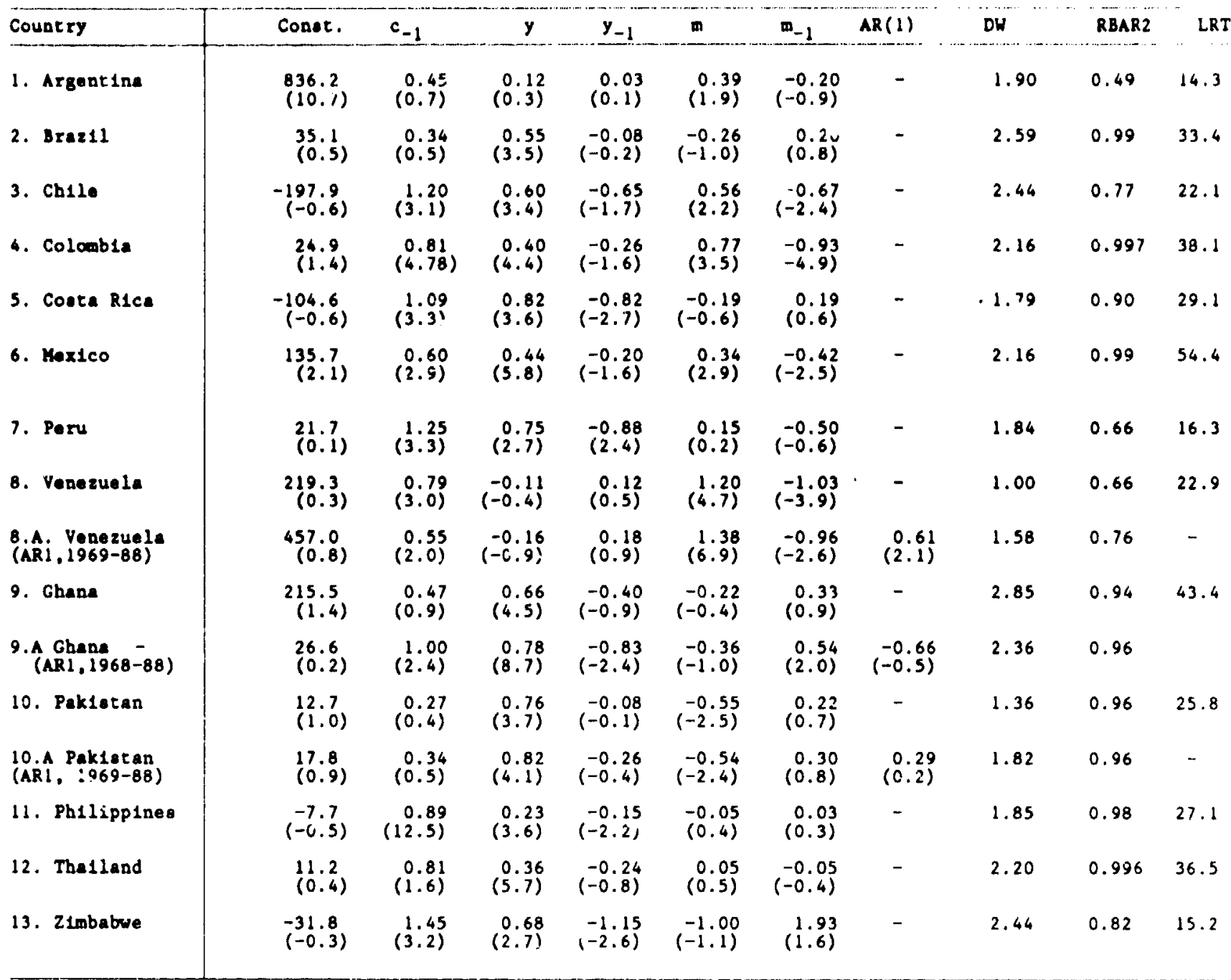

\section{Notee:}

(1)

The specif -ation corresponds to equation (1).

Two etage least squares (TSLS) was used to intrwing al1ze the legged dependent var1able (c curreat income ( $y$ ), using the following four instruments: per capita grose domestic investment. exporta, and the eecond lags of 1 ncome and money.

(111)

L1.les 1-8 present result for all countries, based on TSis without first-order ser1al correlation (AR1). Equations 8.A, 9.A and 10.A present results :or TSLS with AR( 1 ) est lmat lons i corresponding equatlons for the other 10 countries rendered non-olgnificant first-order serial correlation

(1v) t-etatiotice are in parenthes1s, DW 1s the Durbin-Watson etar1stic, and RBAR2 is the adjusted $R^{2}$. coefflclente.

(v) The ame format is used in the other tables.

LRT 18 the $\log 11 \mathrm{kelihood}$ rat1o test otatistic computed for Hall's null hypothesis that only $c_{-1} 18$ - 1 gnificant, based on the difference between $\log$ likelihood values of the above reaults and those of the reatricted specifications. The corresponding value of the $x^{2}$ distribution for a is confidence level and 4 degrees of freedom to 13.3 . 
Table 2.2

CONSUMPTION IN ERURLOPING COUHTRIES (13 COUNTRIES, $1968-1988)$ (ilxed Effecte Panel batinntion)

Deperdent Variable: Per Capita Private Coneumption (c)

\begin{tabular}{|c|c|c|c|c|c|c|c|c|c|}
\hline & & $c_{-1}$ & $y$ & $y_{-1}$ & m & $m_{-1}$ & {$[\cdot \mathbf{W}$} & RBAR 2 & PT \\
\hline & Panel Unwe1ghted LS & $\begin{array}{c}0.85 \\
(16.6)\end{array}$ & $\begin{array}{l}0.25 \\
(5.0)\end{array}$ & $\begin{array}{r}-0.20 \\
(\cdot 3.5)\end{array}$ & $\begin{array}{r}0.50 \\
(9.0)\end{array}$ & $\begin{array}{r}-0.44 \\
(-7.2)\end{array}$ & 1.79 & 0.74 & 66.7 \\
\hline & Panel We1ghted is & $\begin{array}{r}0.78 \\
(16.8)\end{array}$ & $\begin{array}{l}0.27 \\
(7.8)\end{array}$ & $\begin{array}{r}-0.15 \\
(-3.6)\end{array}$ & $\begin{array}{c}0.43 \\
(8.0)\end{array}$ & $\begin{array}{l}-0.43 \\
(-7.3)\end{array}$ & $1 .: 0$ & 0.95 & 92.0 \\
\hline
\end{tabular}

Dependent Variable: Change in per caplta

private conoumption $\Delta c=c-c_{-1}$

\begin{tabular}{|c|c|c|c|c|c|}
\hline & & $\Delta y$ & $\Delta m$ & DW & $R B / R 2$ \\
\hline 3 . & Panel Uawe1ghted IS & $\begin{array}{r}0.36 \\
(7.9)\end{array}$ & $\begin{array}{r}0.49 \\
(9.2)\end{array}$ & 2.06 & 0.46 \\
\hline 4. & Panel Welghted is & $\begin{array}{r}0.41 \\
(12.9)\end{array}$ & $\begin{array}{c}0.30 \\
(5.8)\end{array}$ & 2.09 & 0.54 \\
\hline
\end{tabular}

\section{Notes:}

(1) The specification corresponds to equation (1).

(11) Fitted, not actual, values for lagged private consumption and current GNp values were used for $c_{-1}$ and $y$, respectively, to account for thetr potential correlations with the residuals. The fitted values were obtained from regressing actual $c_{-1}$ and $y$ on the same 4 instruments used in the country-by-cotintry estimations of table 2.1, mentioned in the note to that table.

(11) The t-statistics were corrected using the variance-covariance matrix corresponding to the actual (and not fitted) values of $c_{-1}$ and $y$.

(1v) The weighted LS panel results correspond to the specification with weighted residuals to take care of heteroskedasticity resulting from combining different country data.

(v) FT is the F-test statistalc computed for Hall's null hypothesis that only $c_{-1}$ is olgniflcant, based on the differences between the restricted and unrestricted $R^{2} s$. The corresponding value of the $F$ distribution for a 17 confidence level is 3.1 .

(v1) Results for estlmations with Seemingly Unrelated Regressions (SUR) technique were similar to those presented above:
0.80
0.28
$(23.0)$
$(15.5)$
$y-1$
-0.21
$(-8.1)$
0.47
$(17.2)$
$\mathrm{m}_{-1}$
$-0.42$
$(-8.1)$
$(17.2)$
$(-17.3)$ 
Table 2.2 presents fixed-effucts panel estimation results for the 13 countries, for both unwelghted and welghted least squares (11nes 1 and 2 , respectively). the latter to take care of heteroskedastic1ty otenming from having a different variance for the random error of the equation for different countries." Each consumption determinant contributes vesy olgnificantly to private consumption in the sample of developing countries during 1968-88.

Simila: conclusions were reached using the seemingly unrelated regressions technique, with cross equation restrictions". The cousumption random walk hypothesis is strongly rejected, as reflected by the F-test values. While lagged consumption as a proxy for the permanent income hypothesis has a high value, it differs algnificantly from unity, and current income and money are additional, important determinants of consumption. On the other hand, the extreme Reyriesian hypothesis and the money liquidity constraint hypotheslo are aloo separately and jointly refected as the only determinants of censumption.' The same conclusion way be reached with the panel data estimations for the first difference of consumption as a linear function of the first difference of income and money (table 2.2 lines 3 ard 4 ). Hence private consumption in developing countries seems to conform to the existence of (at least) two distinct groups of private argents, as reflected by equation (1). The significant role of current income and real wrney it. private consumption is a first, indirect evilence that fiscal policles, and particularly changes in public saving, are not fully offset by changes in private saving. Our next seciton is devoted to obtain more direct evidense on how much does the private sector react ro changes in fiscal policies.

However, the values of the coefficient for lagged consumption far away from one create some doubts on the interpretation of the estimations. In general

'To address the potential biases steming from including lagged consumption and current income, we used fitted (not actual) data for these two varlables, obtained from running first-stage regressions as explained in note (11) of table 2.2 .

${ }^{6}$ See note $(v i)$ in Table 2.2 .

The corresponding test statistics were not presented in table 2.2. 
these results should be taken with caution for two main reasons. First, the main source of varlation in the right. hand side variables is likely to be common across regressors making almost impossible the identification of individual coefficients (aithough combination of them will be idertified). Second, the Individual t-statistics should also be taken with caution. These two problems are more important in small samples. To avold in part these problems we also worked with first differences in the varlables in the panel data estimation. However, the resules shown in ines 3 and 4 of table 2.2 also strongly support the hypothesis that liquidity and wealth constraints are important determinants of cc isumption in developing countries.

\section{Private Consumption and Public Policies}

This section broadens the empirical analgsis carried out up to here by spectfying a framework to address directly the effects of public policies on consumption in developing countries.

Direct effects of fiscal policies on consumption or saving operate through public saving (or the deficit) and its composition. If the stringent conditions requtred for Ricardian equivalence are satisfied (1.e. If the private sector is rational forward looking satisfying the $P I H$, and 1 s able or willing to incorporate the intertemporal public budget constraint into 1ts own), a rise in public saving, if it is done via lower public spending, is exactly offset by an increase in private consumption. As disposable income does not change, the reduction in private saving matches the increase in public saving. A rise in public saving does not affect private consumption at all if it is made possible via higher taxes. But as disposable income is reduced by the size of the tax, the reduction in private saving also matches the increase in public saving (the latter being macroeconomically equivalent to issuing more public debt). The opposte results are predicted by the Keynesian (and permanent income without Ricardian equivalence) hypothesis: current (permanent) taxes matter for consumption, not current (permanent) public spending levels.

The Ricardian hypothesis has been widely rejected in empirical studies for 
Industrialized countries. Most of these studies identify the existence of pervasive borrowing constrainte as the main cause for 1ts rejection." A study for a set of developing countries by Montiel and Haque (1987) tests for two different causes which could explain a deviation from Ricardian equivalence: higher private than government discount rates (due to BlanchardYaarl Infinite-lived households facing a mortality probability) and liquidity constraints. They find significant evidence for the latter causing a deviation frow Ricardian equivalence without much support for the former. Borrowing conetraints, proxied by current income or financlaj. asset holdings, are also major determinants in the cross-developing country studies for private consumption and household saving by Rossi (1985) and Schmldt-Hebbel, Webb, and Corsett1 (1990), respectively.

Indirect effects of public (flscal-monetary) policles on private consumption operate via the impact of public deficits and their financing on major prices affecting private consumption: real interest rates, inflation, and the real exchange rate. Real interest rates affect private consumption only if the well-known substitution, income and wealth effects do not cancel each other. This seems not to be the case, judging from the growing evidence which shows that consumption is not sensitive to real interest rates." While Inflation's first order effect is on the composition of the stock of savings and not on saving or consumption, it may have second-order effects reducing measured saving if it is associated to capital flight or flight into consumer durables,

- For Ricardian equivalence to hold, the main conditions to be satisfied folntly are: absence of iiquidity constraints, equal rates of discount for the public and private sectors, and certainty on future 1rcome, tax and public sector expenditure flows. For a further discussion of these conditions and surveys of the empirical studies see Hagashi (1985), Bernheim (1987), and Leiderman and Blejer (1989).

'Among the studies on the interest-insensitivity of saving in developing countries see, for instance, Giovannini (1985) and Schmidt-Hebbel, Webb, and Corsett1 (1990). Por an alternative view, see Pry (1988) and Balassa (1989). The cancellation of income and substitution effects of real interest rates on consumption was confirmed in Southern Cone countries by Schmidt-Hebbel (1987) and Arrau (1989), who obtained elasticities of intertemporal consumption substitution in the neighborhood of 1 . 
or Increasing actual (precautionary) saving if it raises uncertainty. An expected devaluation reduces the consumption-based real interest rate and leads to capital flight - the first effect could increase actual consumption while capital flight raises the measured consumption to income ratio if capital flight reduces measured income. ${ }^{10}$

Monetary pollcy and financial reform affect the aggregate of wonetary and quas1-monetary assets. Broad money increases consumption because 1t reduces the extent of liquidity constraints (as discussed in section 3 ), and is a major component of financial wealth.

Pinally, and less related to direct public policies, forelgn saving impacts on private consumption when it is a (partial) substitute for private saving in a regime of binding foreign resource constraints.

Let's start the discussion of a relevant framework for assessing the impact of public policies on private consumption by referring to a standard form for testing the Ricardian equivalence proposition, based on Bernhelm's (1987) surveg:

$$
\begin{aligned}
C_{p t}= & \alpha_{0}+\alpha_{1}\left(Y N_{t}-T_{t}+I_{t} D_{t}\right)+\alpha_{2}\left(T_{t}-E_{G t}-I_{t} D_{t}\right)+ \\
& +\alpha_{4} D_{t}+\alpha_{5} W_{t}+v_{2 t}
\end{aligned}
$$

where $C_{p}$ is private consumption, $Y N$ is national income, $T$ is tax revenue net of transfers and subsidies to the private sector, 1 is the nominal interest rate, $D$ is government domestic debt, $E_{G}$ is public spending, W is private wealth (net of governmen i domestic debt), and $v_{2}$ is a stochastic error term. Hence the first right-hand determinant is private disposable income and the second is the nominal or total government surplus.

Three simple null hypotheses can be rested with this specification:

(1) Reynesian hypothesis : $\alpha_{0}>0, \alpha_{1}>0$, other coefficients 0 ;

10 For the theory and the Latin American experience on the role of consumption-based real interest rates on intertemporal consumption allocation see Dornbusch $(1983,1985)$, and for the relation between saving and capital flight see Dornbusch (i989). 
(11) Permanent income hypothesis without Ricardian equivalence: $\alpha_{4}>0, \alpha_{3}>0$, other coefificients 0 ;

(111) Ricardian equivalence hypothesis: $\alpha_{1}=\alpha_{2}>0$, other coefficients equal to 0 .

Th1s standard specification presents various shortcomings." First, public saving and not the public surplus should be the relevant determinant in equation (2), because public investment adds to real capital and therefore constitutes "net wealth" in the sense of Barro (1974). Second, under Inflation only the real component of domestic interest payments should enter both private disposable income and the government surplus (saving) ${ }^{12}$. Th1rd, permanent, not current private disposable income and public surplus (saving) should enter (2) for a fair test of the Ricardian proposition. Fourth, additional potential consumption determinants, such as foreign payments and the real interest rate or inflation, should be included. Finally, the role played by the public sector surplus may not reflect Ricardian behavior but could obey to direct crowding-out effects and to institutional arrangements by which the public sector captures private saving either directly or through the domestic financial markets. As both hypotheses are not distinguishable, one should refer to the joint Ricardian/direct crowding-out hypothesis when introducing the public sector surplus as a private consumption determinant.

The following specification for the private consumption to private disposable income ratio takes care of the above mentioned shortcomings of equation (2). In addition, the scaling to private disposable income reduces the extent of non-stationarity of the time series and makes cross-country data comparable. Hence the private consumption rate is specifled as: below.

11 Bernheim (1987) addresses the third and fourth limitations discussed

12 The Inflation component of interest payments on the public debt, which compensates for the loss in principal due to inflation, is put back into public bond holdings by private investors. For a further discussion see Tanzi et al. (1987). 
(3) $\frac{C_{P_{t}}}{D Y_{P t}}=B_{0}+B_{1} \frac{P D Y_{t}}{D Y_{P t}}+B_{2} \frac{P S_{a t}}{D Y_{P t}}+B_{3} r_{t}+B_{4} I N F_{t}+B_{s} \frac{M_{t}}{D Y_{P t}}+$

$$
+B_{6} \frac{F S_{t}}{D Y_{P t}}+v_{3 t}
$$

where $D Y_{p}$ is current private disposable income, PDY is permanent private disposable income, $\mathrm{PS}_{G}$ is permanent public saving. I the real interest rate, INF is domestic inflation, M lo broad money. FS 18 foreign saving, and $u_{3}$ is a stochastic error term.

Permanent private disposable income and permanent public saving are consistent with the following definitions for their corresponding current values:

(4) $D Y_{P t} \equiv G D P_{t}-N_{F P}-T_{t}+r_{t} D_{t}$

(5) $S_{G t} \equiv T_{t}-C_{G t}-N F P_{G t}-T_{t} D_{t}$

where GDP is gross domestic product, NFP $P_{P}$ is net foreign payments made by the private sector, $S_{G}$ is current public saving, $C_{G}$ is public consumption, and $N_{G} P_{G}$ is net foreign payments made by the public sector.

Note that now the coefficients $B_{0}, B_{1}$, and $B_{2}$ in equation (3) reflect more appropriately the Keynesian, permanent income, and Ricardian.'direct crowding out hypotheses, respectively. According to the definition in (4), public saving is now consistent with the operational public deficit concept. Under the Ricardian hypothesis, $B_{1}=B_{2}$, and hence the Ricardian permanent private disposable income concept results from adding $P D Y$ and $P S_{G}$, which is permanent GDP net of permanent total net foreign payments and permanent public consumption. Under the direct crowding-out hypothesis, $B_{2}$ is positive and could easily be larger than $B_{0}$ or $B_{1}$.

Using a data set for operational non-financial public sector deficits for the 1980-87 sample of 13 developing countrles introduced in section 2, we proceed 
to estimate equation (3) for that sample.:' Due to the brevity of the avallable time series we are restricted to a panel estimation. Table 3.1 presents the estimation results for a fixed-effects weighted lest squares panel. The results differ by the assumptions made on permanent public saving, "the inclusion of the rates of real interest and inflation, money, and period-dummes for 1980-82 or $1980-83.1516$

The results tend to be quite robust to the different specifications and estimation methods. While the marginal proponoity to consume out of current private dieposable income hovers around 0.60 (the fixed-effect constants. mentioned in footnote 16, vary between 0.49 and 0.79 , depending on each country). the propensity to consume out of permanent income is significantly lower, varying around 0.24 . Therefore there 1s only partial evidence for intertemporal consumption smoothing in these developing countries: for each percentage point increase in current (transitory) income vis-a-vis permanent income, the private consumption rate declines by one fourth -- much less than the 1.0 fall predicted by the PIH.

Private consumers respond to long-term or "permanent" public saving, however, by much less than the 1.0 coefficient predicted by elther the Rlcardian or direct crowding-out propositions. Nonetheless, the impact of public saving 1s sizable: for each $\$ 1$ increase in public saving, private consumption

\footnotetext{
${ }^{13}$ On variable definitions, sources and transformations see appendix 2 , which also presents in table Al country-by-country time serles of operational consolidated non-financlal public sector deficit, public saving, private saving. and private disposable income, all scaled to GDP.

14 Under the first hypothesis of partial forward-looking expectations, PS Gt 1s constructed as an artehmetic average of current and future, actual public saving, two perlods into the future, while under the static expectations alternative current public saving is used (See appendix 2).

${ }^{15}$ The 1980-82 (1980-83) dummies test for a structural break in 1983 (1984) due to the eruption of the debt crisis and/or domestic recessions, not sufficiently captured by the changes in the business cycle (PDY $/ D Y_{p}$ ) and foreign saving (FS/DY $)_{p}$ ). The dumies are 1 for $1980-82$ (83), 0 otherwise.
}

${ }^{16}$ The fixed-effect coefficients for each country, corresponding to the estimations of table 3.1 , are avallable on request. 
Table 3.1

PRIVATE CONSUMPTION IN DEVELOPING COUNTRIES (13 COUNTRIES, 1980-1987) (Flxed-2ifect Welghted Least Squares Panel Estimation)

Dependent Variable: Private Consumption to Private Dispoable Income Rat1o ( $\mathrm{Cp} / \mathrm{DYp}$ )

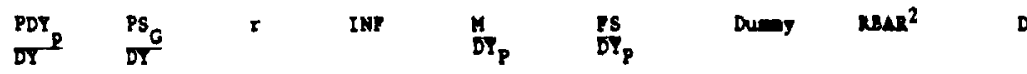

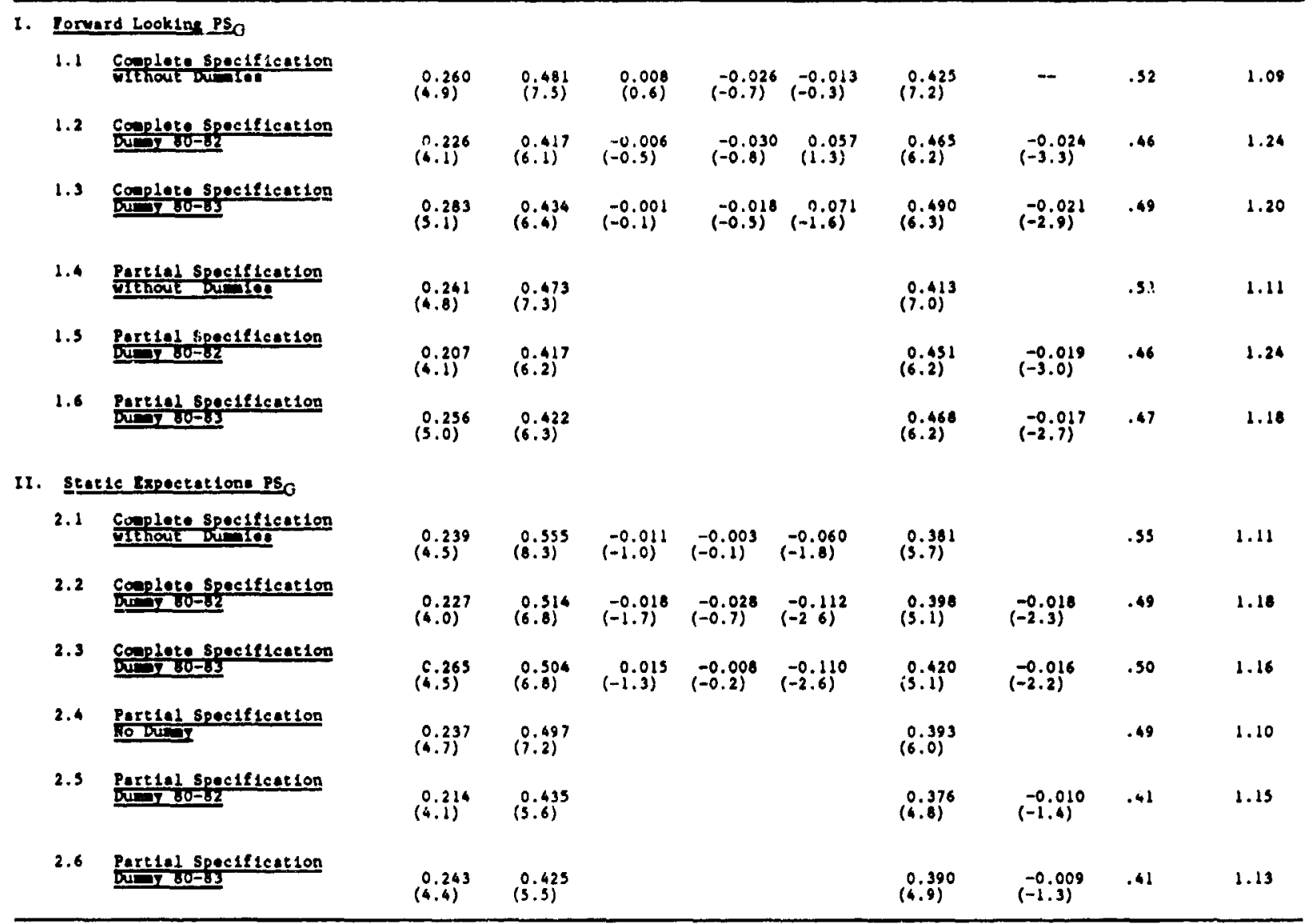

Notes:

(1) The epecification corresponds to equation (3).

(11) The weighted least squares panel results correspond to a specification with weights to take care of heteroskedasticity resulting from combining different country data.

(111) Fitted forelgn saving values and not actual values were used in the regressions, in order to adress the possible simultaneity between consumption and the current account deficit during 1976-1981. The regressore of forelgn saving were lagged forelgn saving. permanent income over actual income and lagged permanent income over actual income.

(1v) Different specifications with dumies for Argantina and Venezuela during oome sub-periods were trled. Although the Improvement in fits were large (RBAR2 around .80). there were only alight changes in the values of the parameters. 
Increases (private saving declines) by an average $\$ 0.44$ (under the forwardlooking hypothes18), to $\$ 0.49$ (under the static expectations hypothes18). We hypothesize that this coefficient reflects both direct crowding-out effects of public deficlt financing and Ricardian behavior of private coneumers, and possibly wore the former than the latter. ${ }^{\prime \prime}$

Real interest rates, Inflation rates, and broad money do not have consistently significant influences on private consumption in our results. Hence lines 1.4-1.6 and 2.4-2.6 of tables 3.1 present results omitting these variables.

The coefficient of the real interest rate 18 negative in most resulto, but never attains otandard acceptable significance levels. This is consistent with most of the empirical literature, as discussed above. Similarly, Inflation has a non-oignificant, small and negative influence or private consumption.

Broad money plays an ambiguous, non-significant role under the forwardlooking specification. However, it shows a small, negative and significant coefficient under the static-expectations alternative, contradicting our priors with regard to its $81 \mathrm{gn}$.

Pinally, forelgn saving has a major and consistently positive effect on private consumption in our sample of 13 developing countries. According to the results, forelgn saving is a partial substitute of private saving: for each $\$ 1$ increase in the current account deficit, private consumption increases by an average $\$ 0.42$, the remainder financing public consumption or gross domestic Investment.

The results discussed here tend to reject the Keynesian, permanent income and Ricardian/direct crowding-out hypotheses in their extreme forms, which exclude all other theories. In fact, there is strong evidence for the joint contribution of Keynesian cum liquidity constraint determinants as well as permanent income and Ricardian/direct crowding-out elements in explaining developing countries private consumption in the eighties. However, it is more illuminating to compare

\footnotetext{
${ }^{17}$ Direct crowding out of private consumption by public deficit can occur in countries where the public sector has preferential access to resources of the private sector. This is the case in some of our sample countries, such as Tha1land and Zimbabwe.
} 
the relative magnituve of the ignificant determinants of private consimption or aving than to atick to the straightforward refection of each of the 1 imple theorfees precisely this is one of the objectives of the next section.

\section{Ratimating the Effects of Public Sector Saving on Private Saving}

To anelyze the Impact of public saving on private saving and hence on national saving, we make use of the results for private consumption behavior reported in table 3.1 based on equation (3). Rewrite equation (3) In terms of private eaving levelo and use the coefficlents of table 3.1 for the following private saving equations:

$$
\begin{aligned}
& \text { (6.1) } \mathrm{S}_{\mathrm{pt}}=\left(1-\operatorname{cons}_{1}\right) \mathrm{DY}_{\mathrm{Pt}}-0.24 \mathrm{PDY}_{\mathrm{Pt}}-0.47 \mathrm{PS}_{\mathrm{Gt}}-0.41 \mathrm{PS}_{\mathrm{t}} \\
& \text { (6.2) } \mathrm{S}_{\mathrm{pt}}=\left(1-\operatorname{cons}_{1}\right) \mathrm{DY}_{\mathrm{pt}}-0.24 \mathrm{PDY}_{\mathrm{Pt}}-0.50 \mathrm{PS}_{\mathrm{Gt}}-0.39 \mathrm{FS}_{\mathrm{t}}
\end{aligned}
$$

where the coefficients in (6.1) are the eatimated parameters presented in line 1.4 of table 3.1 (forward-looking permanent public saving), and those in (6.2) are consistent with the parameters of 2.4 (static-expectations permanent public saving). The country-specific coefficient cons 1 is the fixed-effects parameter for country 1 .

Table 4.1 computes the partial effects on private saving of various changes In income and fiscal policy variables, calculated from equations (6.1) and (6.2) after substituting the identities (4) and (5). As already discussed in section 3, private saving (or consumption) in developing count-ies tends to be more sensitive to current than to permanent income shocks, with corresponding marginal propensities in the neighborhood of 0.40 and 0.24 , respectively (table 4.1 , IInes 1 and 3 ).

For each $\$ 1$ Increase in "permanent" or longer-term public saving, achieved by a "permanent" $\$ 1$ decrease in public consumption, private saving declines by 47-50 cents - a far cry from the 1.0 offset coefficient predicted by the Ricardian/direct crowding-out hypotheses (Iines 4 and 5 ). If the "permanent" 
public deficit reduction to achieved by reducing the long-term tax burden, private saving falls by 23-26 cente for each $\$ 1$ increase in permanent taxation (1ine 6). Note that if permanent income and permanent public oaving had the same coefficlent, which would be a necessary (but not oufficient) condition for Ricardian equivalence to hold, the effect of long-term taxes on private oaving would be nil.

The responsiveness of siving to current income and fiecal policy shocke depends significantly on how the private sector forms 1 ts expectations on permanent variables, as can bo seen when comparing the propeneitles in columno 1 and 2 of table 4.1 .

Hence a $\$ 1$ increase in current public saving (which determines expected permanent public saving fully under static expectations but only partly under partial perfect foresight), achieved by reducing current public expenditure, reduces private saving by 16 to 50 cents, depending on the underlying expectations. However, if the reduction of the current public deficit is pursued via Increasing current taxes, the effect would be much otronger, as a tax Increase affects current and expected permanent private disposable income, in addition to permanent public saving. For each $\$ 1$ of higher current taxes, private saving declines on average (through countries) 48 or 65 cents, depending on how expectations are for id.

From the empirical results we have found that in the short to medium term an increase in public saving has a strong positive effect on national saving. However, the way in which the increase takes place -- Incresse in current taxes or decrease in current expenditures -- and the way by which expectations are formed, affect oignificantly the final impact.

It is cleck from our empirical work that, in the short to medium run, raising public saving is the most effective and oure way to increase national saving. Ralsing public saving, for a given level of public investment, also contributes to reduce the public sector deficit and therefore restores macro balances. Summers (1985) has made the same polfcy recomendation for the U.S., 
Table 4.1

RESPONSE OF PRIVATE SAVING TO CHANGES IN PUBLIC SAVING,

\section{PUBLIC EXPEND ITURE AND TAXES}

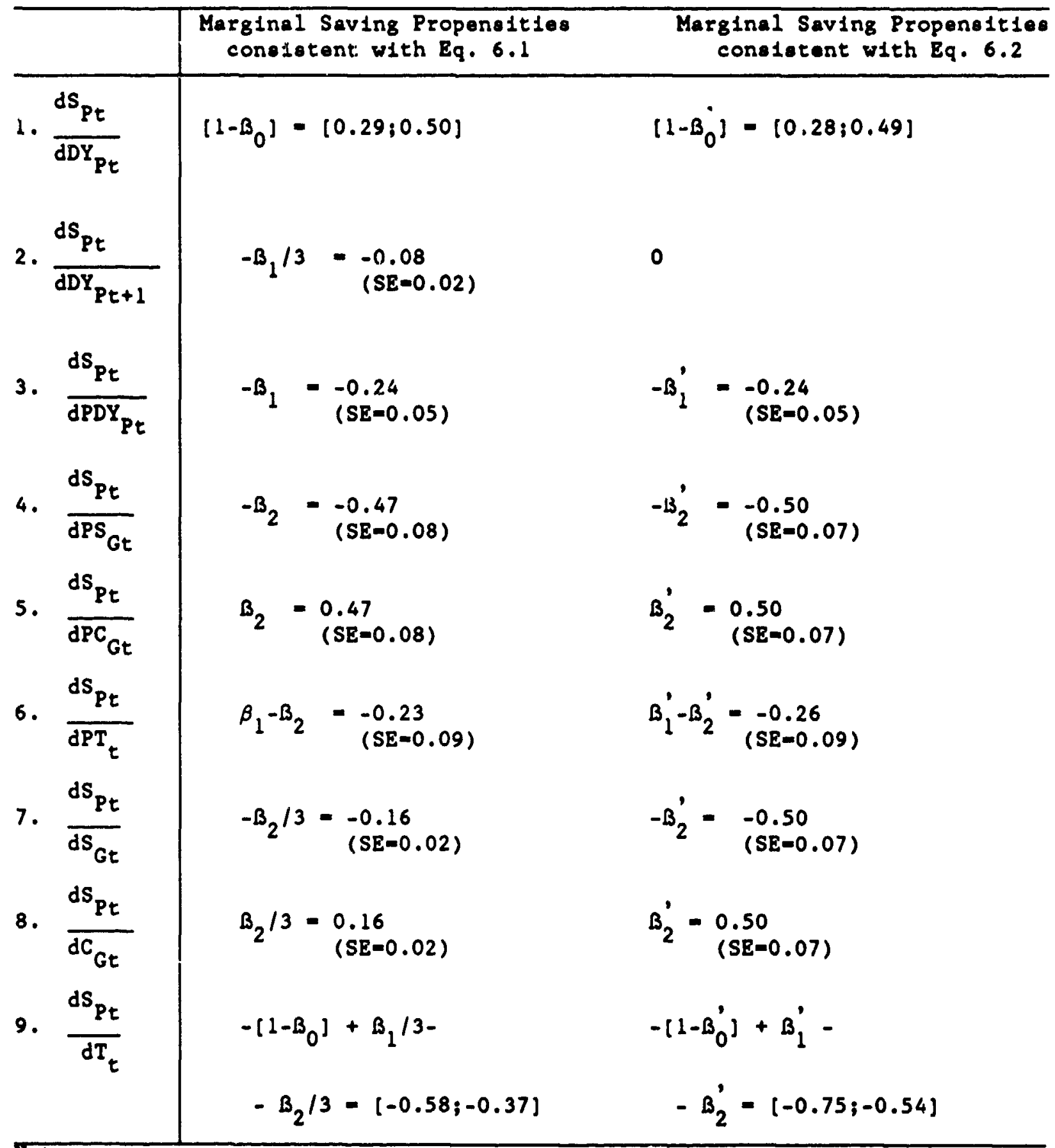

Notes

(1) SE corresponds to the standard error of the parameter(s).

(11) Lines 1 and 9 show the winimum and maximum country fixed-effects coefficlents cons. 
quoted at the etart of thie paper. Increasing public aaving helpo councries experiencing higher Inflation and unoustainable current account deficits. For countries that have already made progress in stab1lization but need now to otart growlng again, raleing public saving -- for a given level of a sustainable current account deficit -- will be required for achlaving higher investment lovelo (both private and public). The problem in many countrles to to find ways of ralaing public saving. Here most countrles will need to work on many fronts.

F1ret, the narrow public revenue base can be axtended through improving tax administration and the Introduction of broadly based unfform rate taxes, such as VATs, and Increased reliance on user charges for the provision of public services with appropriate compensation schemes to protect the poor. Second, public expenditures have to be scrutinized more carefully in terms of thelr costs and benefite. In many countries, public expenditures should be shifted toward high priority, oocial and phyolcal infrastructure and away from 1ll-conceived subsidies and low-return capital expenditure. Third, reforms in local government and state enterprises are required. Decentralizing speniing and revenue authorities can improve the efficlency of the public sector by having a more direct link between the costs and benefits of local services. Public enterprises can increase their contribution to government saving by rationalizing pricing policles, 1mproving their efficiency and a more careful evaluation of their Investment projects.

\section{Conclusions ${ }^{18}$}

The analgois of this paper suggests that if the objective of developing countries is to incresse their national saving rate, then public policy could be used to reach tinls goal through an increase in government saving. From the empirical estimations we found that a $\$ 1$ transitory increase in public oaving, achieved by cutting curzent-period public expenditures, reduces private saving by 16 to 50 cents. However, If the same increase in public saving to achieved

\footnotetext{
${ }^{18}$ The source of the data mentioned in this section 1s Easterly (1989).
} 
by raleing current-period taxes, private eaving declines on average between 48 to 65 conta. The main source of the differential effect of reducing government expenditure vio-a-vio Increasing taxes arises from the effect of tax Increases on both current and permanent income levelo. Por lasting public sector reforms, 1t 1. more 1mportant to aseess the effects of permenent flocal policy changes. Not auprisingly, higher permanent taxation has a smaller effect on pitvate eaving than that of a transitory tax hike: for each $\$ 1$ increase in permanent taxes, private oaving declines only by 23 to 26 cents. Permanent public expenditure cuts, however, reduce private oaving by $47-50$ cents for each dollar, due to the full, combined Ricardian/direct crowding-out effects of permanent public saving on private saving.

The optimal combination of tax increases and current expenditure reductions will undoubtedly depend not only on these coefficlents but also on the inftial -1tuation of each country. Cutting inefficlent current expenditure is - from the viewpoint of growth - the most beneficlal expenditure-side method of reducing public deficits. For Instance, Mexico has been able to reduce the share of nonInterest current government expenditures from $25.5 \%$ of GDP in 1982 to 20.27 in 1987, and Chile from 11.52 of GDP in 1982 to 8.37 of GDP in 1987. For the same time period, Argentina's share went from $20.7 \%$ to 23.17 of GDP.

Increasing taxes and improving tax compliance are the most efficlent methods of reducing public deficits when traditional tax revenue 18 10\% and inefficlent tax levies (such as the inflation tax) are widespread and high. In Brazil, a country with a relatively high initial tax revenue share of GDP, traditional tax revenue fell from 25.12 in 1982 to 21.32 in 1987 , while Inflationary taxation was ralsed. Mexico, on the other hand, was unable to ralse significantly its low traditional tax revenue share between 1982 and 1987 , Increasing it only from 9.97 to $10.5 \%$ of GDP.

Finally, public policy can also make an important contribution to raise measured private saving and the efficiency of its use by providing a macroeconomic framework in which inflation 18 low and incentives are predictable. 


\section{References}

Arrau, R, (1989): "Intertemporal Monetary Economlca: Evidence from the Southern Cone of Latin Amerlca," University of Pennarlvente Ph. D. Diagertation. Philadelphia, Penneglvania.

Balsesa, B. (1989): "The Effects of Intereat Rates on Saving in Developing Countries", manuscript, The World Bank, Waohington, D.C.

Barro, R. (1974): "Are Government Bonds Net Wealth?", Journel of Polftelcal Bconomy, vol. 82.

Bernhe1m, B.D. (1987): "Ricardian Equivalence: an Evaluation of Theory and Evidence", In NBER Macroeconomics Annual 1987, MIT Press.

Corto, V. and J. de Melo (1989): "External Shocks and Policy Reforme in the Southern Cone: A Rearsessment", in G. Calvo (ed.): Debt, Stablifintion and Development, Basil Blackweil.

Dornbusch, R. (1983): "Real Interest Reten, Home Goode, and Optimal External Borrowing", Journal of Polltical Economy, vol. 1, No. 1, Eabruary.

(1985): "Overborrowing: Three Case Studies", in G.W. Smith and J.T. Cuddington: International Debt and the Developins Countries, World Bank.

(1989): "Capital Flight: Theory, Measurement and Policy Isaues", manuscript, M.I.T., Cambridge, Mass.

Easterly, W. R. (1989): "Flocal Adjustment and Deficlt Financing during the Cost Cr1sis", In Husain, I, and I. Diwan (ede.): Deeling with the Debt Crig1s, The World Bank, Washington D.C.

Easterly, W. R. and P. Honohan (1990): "Financial Sector Policy in Thalland: A Macroeconomic Perspective", PRE Working Paper No. 440, The World Bank, Washington D.C.

Fry, M.J. Money, Interest and Banking in Economic Development, Johns Hopkins University, Baltimore.

Glovannin1, A. (1985): "Saving and the Real Interest Rate in LDCs", Journal of Development Economics, vol. 18, August.

Hal1, R.E. (1978): "Stochastic Implications of the Life-Cycle Permanent Income Hypothes 1s: Theory and Evidence", Journal of Political Economy, vol. 86, Ho. 6, December.

Hagash1, F. (1982): "The Permanent Income Hypothes1s: Estimation and Testing by Instrumental Varlables", Journal of Polltical Economy, Vol. 90, No. 5, October.

Hayash1, F. (1985): "Tests for L1quidity Constraints: A Critical Survey", NBER Working Paper 1720, Cambridge, Mass., October.

Hubbard, R.G. and R.L. Judd (1986): "Liquidity Constrainte, R1scal Policy, and Consumption", Brookings Papers on Economic Activity: 1 .

Islam, R. and D. Wetzel (1990): "Macroeconomice of Public Sector Deficites The Case of Ghana", manuecript, The World Bank, Washington D.C. 
Riguel, M. and N. Liviatan (1989): "The Old and the How in Heterodox Stablization Plans: Lessone from the 1960 a ad $1980^{\circ}$ ", PPR Working Paper No. 323, The World Bank, Washington, D.C., December.

Letderman, L. and M. Blejer (1988): "Modeling and Testing Ricardian Equivalence: A Survey", IMP Staff Papers, vol. 35, No. 1, March.

Montie1, P. and N.U. Haque (1987): "Ricardian Equivalence, Liquidity Constraints, and the Yaar1-Blanchard Effect: Teote for Developing Countr1es, IME Work1ng Paper, IMF, Washington, D.C.

Roos1, N. (1988): "Government Spending, the Real Interest Rate, and the Behavior of Liquidity-Constrained Consumers in Developing Countrles", IME Staff Papers, vol. 35, No. 1, March.

Schm1dt-Hebbel, R. (1987): "Terms of Trade and the Current Account under Uncertainty," Analis 18 Economico, Vol. 2, No. 1; June.

Schwidt-Hebbe1, R. (1987): "Fore1gn Shocks and Macroeconomic Adfustment in Small Open Economles," M.I.T. Ph.D. D1ssertation. Cambridge, Massachusetts.

Schmidt-Hebbel, R. (1990): "Zimbabwe: The Need for Fiocsl Adjustment", manuscript, The World Bank, Washington D.C.

Schmidt-Hebbel, K., S. Webb and G. Corsett1 (1990): "Household Saving in Developing Countries: First Crose-Country Evidence", manuscript, The World Bank, Washington, D.C.

Sumers, L. H. (1985): "Issues in National Savings Pol1cg", NBER Working Paper No. 1710 , Cambridge, Massachusetts.

Tanz1, V., M. I. Blejer, and M. O. Teifeiro (1987): "Inflation and the Messurement of Flscal Deflc1ts", IMF Staff Papers, Vol. 34, No.4, December.

World Bank (1990): Second Report on Adjustment Lendin - Washingtor, D.C., forthcoming.

World Bank: World Development Report, Oxford University, various 18sues. 


\section{Append $1 x+1$}

Th1o appendix deriver a par capita consumption function for an economy composed by two groups of consumers. The first group follows Hall's (1978) random walk procese conelstent with the permanent income hypothesie, and the econd 10 either uncertain about 1to permenent income level or 11quidity conetrained in ite conumption decielons. All variables are scaled to the population ize. Hence per capita consumption of the unconstrained private enctor 1e given by:

$$
c_{t}^{u}=\alpha c_{t-1}^{u}+\epsilon_{t}^{u}
$$

where $c_{p}$ 1s private consumption, $\epsilon$ 1s atochastic error form and the supraindex is denotes the unconstrained group. The coefficlent a lo normally equal to 1.

Constrained consumers behave as follows:

$$
c_{t}^{c}=B+\gamma y_{t}^{c}+\delta m_{t}^{c}+\epsilon_{t}^{c}
$$

where $p$ is private income, $m$ Is monetary and quasi-monetary assets, and the oupraindex $c$ denotes the aggregate of constralned and/or permanent incomeuncertain consumers.

Variables referred to each particular group are unobserved, wh1le aggregate economy-wide variables are observed.

Average per capita consumption is a welghted average of each groups' coneumption levele:

(A3) $c_{t}=\mu c_{t}^{u}+(1-\mu) c_{t}^{c}$

where $\mu$ is the share of the consumption constrained population, satisfying $0<\mu<1$.

Solve (A3) for $c_{\text {, }}^{u}$ take one lag of the latter, substitute it into (A1), and then substitute the iatter back into (A3) to obtain:

$$
c_{t}=\alpha c_{t-1}+(1-\mu) c_{t}^{c}-\alpha(1-\mu) c_{t-1}^{c}+\mu \epsilon_{t}^{u}
$$

Per capita current income and financlal holdings of the second group of consumers are proportional to agsregate per capita income and monetary assets as follows:

(A5)

$$
y_{t}^{c}=\lambda y_{t}
$$

$$
w_{t}^{c}=\rho w_{t}
$$


where $\lambda, \rho>0$.

Subetitute (A5) - (A6) Into (A2), and the latter expression into (A4) to obtaln finallg:

$$
\text { (A7) } \begin{aligned}
c_{t}= & (1-\alpha) B(1-\mu)+\alpha c_{t-1}+(1-\mu)(\gamma \lambda) y_{t}-\alpha(1-\mu)(\gamma \lambda) y_{t-1}+ \\
& +(1-\mu)(\delta \rho) m_{t}-\alpha(1-\mu)(\delta \rho) m_{t-1}+ \\
& +\left[\mu \epsilon_{t}^{u}+(1-\mu) \epsilon_{t}^{c}-\alpha(1-\mu) \epsilon_{t-1}^{c}\right]
\end{aligned}
$$

Eetimation of (A7) allows to 1dentify the following (combinations of) parametere: $\alpha, B, \mu,(\gamma \lambda)$, and $(\delta \rho)$.

Equation (1) of the paper is the reduced-form equivalent of (A7).

\section{Append1X 2}

Th1. appendix diecusees variable definitions, date sources and data transformatione corresponding to the variables in equatione ( 1 ) and ( 3 ). It also presente the deta oerieo for the non-financlal public oector deficlt, public aning, private saving, and private disposable income used in the panel estimation of equation ( 3 ).

\section{Original Variables}

The following original variables were obtained from the World Bank ANDREX date base, (which compiles data from U.N. National Accounts, IFS (IMF), and national ources):

\section{(a) Current-Price Local Currency Data:}

Total consumption, money and quasi-money, private consumption and gross dowestic product and gross national product, both at market prices.

(b) 1980 Constant-Price Local Currency Data:

Government consumption, total consumption, gross domestic investment, gross national product at market prices, goods and non-factor services exports and private consumption.

(c) Population Data: Total population.

(d) Price Data: Period average exchange rate.

The following original variables were obtained from the SAVEM data base, World Bank (which compiles data from U.N. National Accounts, among other eources):

Current-P̌rice Local Currency investment, gross national saving and GDP.

The source of the nominal interest rate 18 the IFS data bank, IMF.

The sources for the operational non-financial public sector deficit ( $z$ of GDP, at current prices) for Latin Amer1can countries ares 
(a) Argentina: Rigue1, M. and N. Liviatan (1989) and ECLAC Profect on Flocal Pollcles, Santiago, Chile.

(b) Braz11, Chile, Colombia, Costa Rica, Mexico, Peru and Venezuela: ECLAC Prolect on Plscal Policies.

The sources for non-financial public sector investment ( $z$ of GDP, at current prices) for Latin American countries are:

(a) Argentina, Braz1l, Chile, Costa Rica and Venezuala: ECLAC Project on Flacal Policies.

(b) Colombia: Colomb1a CEM, World Bank.

(c) Mexico: proportion of Public Investment/Grose Domestic Investment at constant prices, from Banco de Mexico: Indicadoree Económ1cos, Dec, 1989) applied to the Gross Domestic Investment/GDP share (at current prices, from ANDREX, World Bank).

(d) Peru: proportion of Public Investment/Grose Domestic Investment (at constant prices, from IDB: Economlc and Social Progress in Latin Amer1ca, 1989, Table IX-2, p.203) applied to the Gross Domest1c Investment/GDP hare (at current prices, from ANDREX, World Bank).

Additional country-specific varlables for the 5 non-Latin American countries were obtained from the following sources:

(a) Ghana: non-financial public sector deficlt and public investmentiGDI share from Islam and Wetzel (1990).

(b) Pakistan: public sector figures from Pakistan Economic Surver.

(c) Philippines: public sector figures were obtained from Easterly (1989). Figures for 1980 were not avallable; we assumed the 1981 proportion to GDP.

(d) Thatland: public sector figures were obtained from Easterly and Honohan (1990). Figures for 1980 were not avallable; we assumed the 1981 proportion to GDP.

(e) Zlmbabwe: figures for the public sector were obtalned from Schmidt-Hebbel $(1990)$.

\section{Transformed Vartables}

\subsection{For Equation (1)}

The per capita constant-price (in 1980 US\$) series for $c, y$, and m werc obtained by dividing local-currency constant price private consumption, GNP and broad money (the sum of money and quasi-money) by the perlod-average 1980 nomina). exchange rate and the population. 


\subsection{For Equation (3)}

\section{Current-Perjod Variables}

Current-price public saving was obtained by oubtracting the operatiunal non-financial public sector deficit from non-financial public sector investment. To obtain private saving next, elther forelgn oaving and public oaving were subtracted from grose domestic investment or public oavi:g was deducted from gross national saving. Private disposable income to the sum of private saving and private consumption.

Table Al presents the 13-country 1980-87 time serles for the current-price local currency GDP shares of the operational non-financial public sactor deficit, public saving, private saving, and private disposable income. Note that the private consumption/private diaposable income ratio, which is the dependent varlable in equation ( 3 ), to obtained by simple transformations of the two latter varlables.

\section{rermanent D18posable Income}

For the estimate of permanent private disposable incone at current prices (which is divided by current-perlod private disposable income at current prices in equation 3), first real private disposable io obtained by dividing currentprice private diaposable income $\left(D Y_{p}\right)$ by the GNP deflator. Next, for Brazil, Colombia, Pakistan, Thalland and Venezuela constant-price permanent private disposable income (real $\mathrm{PDY}_{\mathrm{P}}$ ) wa's obtained by estimating the 1980-87 deterministic trend. For Argentina, Chile, Costa Rica, Ghana, Mexico, Peru, Philippines, and Zimbabwe the trend was not significant, therefore real PDY was defined as the sample arithmetic average of the real DY series. Finally, current-price permanent private disposable income (PDY) was obtained by multiplying the real PDY, by the GNP deflator.

\section{Permanent Public Saving}

Two extreme alternatives for current-price permanent public saving (which 18 divided by current-period private disposable income at current prices in equation 3 ) were used for the estimations. The first one 18 a partial forward looking option, which specifles expected long-term public saving as an arithmetic average of actual current and future public oaving levels, two periods into the

future: $\quad P S_{G t}=\left[\sum_{i=0}^{2} S_{G t+1}\right] / 3$. The se ind option corresponds to static expectations: $\mathrm{PS}_{\mathrm{Gt}}=\mathrm{S}_{\mathrm{Gt}}$.

Inflation and Interest Rates

The inflation rate, corresponding to the private consumption deflator, was normalized as follows: $\operatorname{INF}=\left(\Delta \mathrm{P}_{\mathrm{ct}} / \mathrm{P}_{\mathrm{ct}-1}\right) /\left(1+\Delta \mathrm{P}_{\mathrm{ct}} / \mathrm{P}_{\mathrm{ct}-\mathrm{l}}\right)$.

The real interest rate $(r)$ is measured ex-post using the standard $F$ isher equation: $r=(1+1) /\left(1+\Delta \mathrm{P}_{\mathrm{at}} / \mathrm{P}_{\mathrm{ct}-1}\right)-\mathrm{l}$, where 1 is the nominal interest rate. 
TABLE AL

Operationel Mon-Iinunelal Public sector Daflele of GDY at curront prico

\begin{tabular}{|c|c|c|c|c|c|c|c|c|c|c|c|c|c|}
\hline & No & $\mathbf{n}$ & CII & COL & CRI & $\operatorname{mx}$ & PER & $\sqrt{*}$ & ous & $\mathbf{P A R}$ & PuI & TI: & $2 \omega$ \\
\hline $\begin{array}{l}1980 \\
1981 \\
1982 \\
1983 \\
1984 \\
1985 \\
1986 \\
1987\end{array}$ & $\begin{array}{l}4.4 \\
8.2 \\
3.6 \\
8.8 \\
8.0 \\
4.6 \\
2.0 \\
6.3\end{array}$ & $\begin{array}{l}1.3 \\
3.4 \\
4.3 \\
3.8 \\
3.1 \\
3.7 \\
2.6 \\
4.3\end{array}$ & $\begin{array}{r}-5.4 \\
-3.4 \\
3.9 \\
3.3 \\
4.3 \\
2.9 \\
1.3 \\
-0.3\end{array}$ & $\begin{array}{r}2.5 \\
6.9 \\
7.5 \\
7.7 \\
6.1 \\
2.9 \\
2.6 \\
-0.7\end{array}$ & $\begin{array}{r}12.1 \\
0.6 \\
0.9 \\
0.9 \\
0.2 \\
0.8 \\
2.0 \\
0.4\end{array}$ & $\begin{array}{r}6.1 \\
10.1 \\
6.0 \\
2.0 \\
1.0 \\
1.9 \\
1.7 \\
-0.5\end{array}$ & $\begin{array}{l}3.9 \\
6.7 \\
7.3 \\
9.8 \\
6.2 \\
2.4 \\
4.9 \\
6.5\end{array}$ & $\begin{array}{r}-4.3 \\
-0.6 \\
12.2 \\
2.2 \\
-10.1 \\
-6.9 \\
1.4 \\
-0.5\end{array}$ & $\begin{array}{r}2.3 \\
0.7 \\
0.0 \\
-2.4 \\
-1.3 \\
0.6 \\
-4.8 \\
-5.7\end{array}$ & $\begin{array}{l}4.6 \\
6.1 \\
3.8 \\
3.6 \\
7.1 \\
9.6 \\
8.6\end{array}$ & $\begin{array}{r}3.0 \\
3.2 \\
1.7 \\
2.8 \\
-2.8 \\
-2.8 \\
-2.3 \\
-2.8\end{array}$ & $\begin{array}{l}8.6 \\
6.7 \\
6.7 \\
5.3 \\
5.5 \\
5.3 \\
3.3 \\
0.3\end{array}$ & $\begin{array}{r}9.8 \\
5.8 \\
10.2 \\
7.0 \\
13.8 \\
15.8 \\
8.2 \\
6.6\end{array}$ \\
\hline
\end{tabular}

(x of oDP of curroat pricee)

\begin{tabular}{|c|c|c|c|c|c|c|c|c|c|c|c|c|c|}
\hline & ARG & $\mathbf{D N}$ & Chll & $\mathrm{COL}$ & CRI & $\operatorname{sed}$ & PR & ves & o:A & PAK & PII & Th:A & $2 \mathrm{z}$ \\
\hline $\begin{array}{l}1980 \\
1981 \\
1982 \\
1983 \\
1984 \\
1985 \\
1986 \\
1987\end{array}$ & $\begin{array}{r}4.7 \\
2.3 \\
2.5 \\
0.2 \\
-0.5 \\
2.2 \\
5.1 \\
3.3\end{array}$ & $\begin{array}{l}8.3 \\
7.7 \\
4.6 \\
3.2 \\
3.3 \\
3.3 \\
7.4\end{array}$ & $\begin{array}{r}10.6 \\
3.5 \\
0.5 \\
1.3 \\
1.3 \\
4.2 \\
9.2 \\
10.4\end{array}$ & $\begin{array}{l}3.2 \\
1: 7 \\
1: 9 \\
1: 1 \\
2: 9 \\
6.7 \\
5.9 \\
9.1\end{array}$ & $\begin{array}{r}0.3 \\
6.1 \\
3.9 \\
10.4 \\
9.6 \\
6.7 \\
10.1 \\
9.1\end{array}$ & $\begin{array}{l}4.6 \\
2.0 \\
4.6 \\
4.6 \\
3.6 \\
1.4 \\
6.4\end{array}$ & $\begin{array}{l}3.1 \\
2.9 \\
6.8 \\
3.4 \\
3.5 \\
6.5 \\
3.2 \\
1.3\end{array}$ & $\begin{array}{l}20.2 \\
19.9 \\
10.5 \\
13.8 \\
21.4 \\
13.8 \\
13.3 \\
12.9\end{array}$ & $\begin{array}{r}4.6 \\
2.3 \\
0.9 \\
-1.7 \\
0.0 \\
2.7 \\
-2.9 \\
-3.2\end{array}$ & $\begin{array}{l}13.5 \\
13.3 \\
16.7 \\
16.0 \\
17.1 \\
17.7 \\
20.4 \\
10.7\end{array}$ & $\begin{array}{r}11.7 \\
13.9 \\
8.3 \\
10.0 \\
1.7 \\
0.6 \\
1.3 \\
2.2\end{array}$ & $\begin{array}{r}16.9 \\
13.0 \\
15.0 \\
12.8 \\
13.2 \\
13.1 \\
10.3 \\
6.8\end{array}$ & $\begin{array}{l}14.5 \\
11.2 \\
20.0 \\
18.1 \\
22.4 \\
21.7 \\
14.0 \\
12.6\end{array}$ \\
\hline
\end{tabular}

(x of corryete Seving

\begin{tabular}{|c|c|c|c|c|c|c|c|c|c|c|c|c|c|}
\hline & $\Delta \boldsymbol{C O}$ & $\mathbf{n}$ & CER & $\cot$ & CRI & $\ln$ & PE & $\sqrt{n}$ & GEA & $\mathbf{P A R}$ & PII & $\mathbf{T H}$ & zL5 \\
\hline $\begin{array}{l}1980 \\
1981 \\
1982 \\
1983 \\
1984 \\
1985 \\
1986 \\
1967\end{array}$ & $\begin{array}{r}14.1 \\
13.5 \\
11.0 \\
13.6 \\
9.0 \\
4.9 \\
0.4 \\
2.0\end{array}$ & $\begin{array}{r}9.2 \\
9.3 \\
10.9 \\
8.2 \\
12.2 \\
13.3 \\
9.5 \\
15.4\end{array}$ & $\begin{array}{r}3.5 \\
2.8 \\
0.5 \\
3.3 \\
1.6 \\
1.5 \\
-2.2 \\
2.6\end{array}$ & $\begin{array}{l}14.6 \\
14.2 \\
11.2 \\
14.3 \\
13.7 \\
12.1 \\
18.8 \\
11.0\end{array}$ & $\begin{array}{r}11.5 \\
7.7 \\
8.3 \\
3.2 \\
3.5 \\
9.5 \\
9.1 \\
10.3\end{array}$ & $\begin{array}{l}17.5 \\
21.5 \\
16.1 \\
19.9 \\
16.5 \\
17.1 \\
16.0 \\
15.2\end{array}$ & $\begin{array}{l}17.8 \\
19.1 \\
15.6 \\
13.8 \\
17.4 \\
15.4 \\
16.1 \\
15.9\end{array}$ & $\begin{array}{r}13.0 \\
-0.3 \\
5.4 \\
3.9 \\
2.0 \\
7.3 \\
3.9 \\
9.4\end{array}$ & $\begin{array}{r}-0.1 \\
1.4 \\
2.5 \\
1.4 \\
3.2 \\
3.2 \\
6.8 \\
8.4\end{array}$ & $\begin{array}{r}-9.8 \\
-7.0 \\
-9.4 \\
-9.0 \\
-10.8 \\
-13.1 \\
-11.5 \\
-7.0\end{array}$ & $\begin{array}{r}13.2 \\
12.6 \\
11.8 \\
1.5 \\
12.8 \\
14.0 \\
15.8 \\
13.6\end{array}$ & $\begin{array}{l}2.4 \\
3.4 \\
5.8 \\
5.2 \\
6.2 \\
6.3 \\
11.8 \\
17.4\end{array}$ & $\begin{array}{r}0.0 \\
2.0 \\
-8.5 \\
-9.2 \\
-3.9 \\
-3.5 \\
5.1 \\
6.7\end{array}$ \\
\hline
\end{tabular}

Private Disposable Incoes

Of GDP at curront pricos)

\begin{tabular}{|c|c|c|c|c|c|c|c|c|c|c|c|c|c|}
\hline & $\mathbf{M Q}$ & $\mathbf{B R}$ & CEII & COL & CRI & $\sec x$ & PER & Van & GHA & PAR & FHI & THA & ZWE \\
\hline $\begin{array}{l}1500 \\
1981 \\
1980 \\
19 \% 3 \\
9886 \\
1985 \\
1986 \\
1987\end{array}$ & $\begin{array}{l}80.3 \\
82.0 \\
79.7 \\
78.3 \\
82.5 \\
78.7 \\
77.5 \\
60.3\end{array}$ & $\begin{array}{l}79.3 \\
79.2 \\
81.2 \\
81.2 \\
83.0 \\
82.0 \\
78.2 \\
77.2\end{array}$ & $\begin{array}{l}74.2 \\
77.5 \\
75.8 \\
76.6 \\
74.6 \\
70.8 \\
66.7 \\
70.2\end{array}$ & $\begin{array}{l}84.8 \\
86.7 \\
84.1 \\
86.2 \\
84.3 \\
81.1 \\
84.1 \\
77.4\end{array}$ & $\begin{array}{l}77.0 \\
67.9 \\
66.1 \\
64.7 \\
66.8 \\
66.1 \\
68.9 \\
70.0\end{array}$ & $\begin{array}{l}82.6 \\
85.8 \\
77.7 \\
80.8 \\
79.8 \\
81.1 \\
83.7 \\
79.3\end{array}$ & $\begin{array}{l}79.1 \\
82.3 \\
77.3 \\
78.6 \\
79.9 \\
77.2 \\
83.6 \\
84.0\end{array}$ & $\begin{array}{l}67.9 \\
57.6 \\
67.8 \\
71.5 \\
64.4 \\
70.1 \\
72.5 \\
74.0\end{array}$ & $\begin{array}{l}83.8 \\
88.6 \\
92.3 \\
92.2 \\
91.1 \\
86.3 \\
89.1 \\
90.0\end{array}$ & $\begin{array}{l}73.3 \\
73.6 \\
71.9 \\
71.2 \\
69.4 \\
68.6 \\
64.8 \\
65.6\end{array}$ & $\begin{array}{l}80.5 \\
80.6 \\
80.6 \\
78.3 \\
87.4 \\
90.6 \\
91.5 \\
87.6\end{array}$ & $\begin{array}{l}69.0 \\
69.1 \\
70.7 \\
71.0 \\
71.6 \\
71.7 \\
77.0 \\
61.4\end{array}$ & $\begin{array}{l}64.5 \\
69.0 \\
56.5 \\
59.6 \\
53.1 \\
52.0 \\
59.6 \\
59.4\end{array}$ \\
\hline
\end{tabular}


RBE Workino Paper_Series

Int

Author

Dete

Contact

Dipak Mazumdar

December 1990

M. Schroior

Structural Adjustment

36432

WPS555 The Macroeconomics of Price Relorm

Simon Commander

December 1990

O. dal Cid in Socialist Countries: A Dynamic

Fabrizio Coricelli

39050

Framowork

WPS556 Taxing Choices in Deficit Reduction

John Baffes

Anwar Shah

December 1990

A. Bhalla

37699

WPS557 The New Fiscal Foderalism in Brazil

Anwar Shah

December 1990

A. Bhalla 37699

WPS558 Ahernative Instruments for Smoothing the Consumption of Primary Commodity Exporters

Kenneth M. Kletzer David M. Newbery

J. Carroll

Brian D. Wright

WPS559 Fiscal Policy and Private Investment in Developing Countries: Recent

Ajay Chhibber Evidence on Key Selected Issues

Mansoor Dailami

December 1990

D. Bilkiss

33768

WP5560 The Persistence of Job Security in Reforming Socialist Economies

Milan Vodopivec

December 1990

CECSE

37188

WPS561 The Labor Market and the Transition Milan Vodopivec of Socialist Economies

December 1990

CECSE

37188

WPS562 Anticipated Real Exchange-Rate

Luis Serven

December 1990

S. Jonnakuty Changes and the Dynamics of

Investment

WPS563 Empirical Investment Equations in

Developing Countries

Martin Rama

December 1990

E. Khine

39361

WPS564 Costs and Benefits of Agricultural

Avishay Braverman

December 1990

C. Spooner

Price Stabilization in Brazil

Ravi Kanbur 30464

Antonio Salazar P. Brandao

Jeffrey Hammer

Mauro de Rezende Lopes

Alexandra Tan

WPS565 Issues in Socialist Economy

Stanley Fischer

Decemter 1990

CECSE

Relorm

Alan Gelb

37188

WPS566 Measuring Outward Orientation in Lant Pritchett

Developing Countries: Can lt Be Done?

January 1991

K. Cabana

37947

WPS567 Macroeconomic Management and the Antulio N. Bomfim

Division of Powers in Brazil:

Anwar Shah

January 1991

A. Bhalla

37699 


\section{WPS568 Higher Wages for Relief Work Can Make Many of the Poor Worse Off: Recent Evidence from Maharashtra's "Employment Guaranteo Scheme" Import License Allocations in Mali

$\begin{array}{ll}\text { WPS570 } & \begin{array}{l}\text { Debt Concentration and Second } \\ \text { Market Prices }\end{array} \\ \text { WPS571 } & \begin{array}{l}\text { Credit's Effect on Productivity in } \\ \text { Chinese Agriculture: A } \\ \text { Microeconomic Model of } \\ \text { Disequilibrium }\end{array} \\ \text { WPS572 } & \begin{array}{l}\text { Capital Positions of Ja, anese } \\ \text { Banks }\end{array}\end{array}$

WPS569 Domestic Purchase Requirements lor Wendy E. Takacs

WPS573 Malaysian Labor Markets Under Structural Adjustment

WPS574 Public Policies and Saving in Developing Countries

WPS575 Household Saving in Developing Countries: First Cross-Country Evidence

WPS576 Lessons from Tax Reform: An Ovenview

WPS577 Africa's Rising Inflation: Causes, Consequences, and Cures

WPS578 The Bank's Use of Technical Assistance for Institutional Development

WPS579 Chile's Experience with Stabilization Revisited

WPS580 Do Natural Resource-Based Industrialization Strategies Convey Important (Unrecognized) Price Benelits for Commodity-Exporting Developing Countries?
Martin Ravailion

Gaurav Datt

January 1991

Shubham Chaudhuri

Haquel Fernandez

Sule Ozler

Gershon Feder

Lawrence J. Lau

Justin $Y$. Lin

Xiaopeng Luo

Edward J. Kane

Haluk Unal

Asli Demirguc-Kunt

Dipak Mazumdar

Vittorio Corbo

Klaus Schmidt-Hebbel

Klaus Schmidt-Hebbel

Steven B. Webb

Giancarlo Corsetti

Wayne Thirsk

January 1991
A. Bhalla
37699

Ajay Chhibber

Beatrice Buyck

January 1991

\section{E. Madrona} 37496

Vittorio Corbo Andrés Solimano

January 1991

E. Khine 39361

Alexander J. Yeats

January 1991

J. Jacobson 33710 